\title{
EFFECT OF TEXTILE EFFLUENT ON THE YIELD OF JUTE LEAVES (Corchorus capsularis) IN WINTER SEASON
}

\author{
Begum, M., M. N. Gani ${ }^{1}$ and M. D. Alam $^{2}$ \\ Soil and Environmental Sciences, University of Barisal, Bangladesh; ${ }^{1}$ Fiber Quality Improvement \\ Division, Bangladesh Jute Research Institute, Dhaka Bangladesh; ${ }^{2}$ Department of Soil, Water and \\ Environment, University of Dhaka, Bangladesh
}

\begin{abstract}
A pot experiment was conducted to observe the effect of textile effluent on the yield of newly developed deshi pat shak-1 (Corchorus capsularis), in winter season by the Bangladesh Jute Research Institute (BJRI). There were six treatments of different effluent level including different proportions of fresh water and Recommended Dose of Fertilizer (RDF). It was observed that all the treatments showed significant positive effect on the yield parameters of jute vegetables over the control on agricultural soils. However, in contaminated soils effluent irrigation showed negative effect over the control. The highest yield of vegetative weight in all soils was observed in the treatment $\mathrm{T}_{2}$ where fresh water $+100 \% \mathrm{RDF}$ were applied. They were $8.83 \mathrm{t} / \mathrm{ha}, 8.93 \mathrm{t} / \mathrm{ha}, 9.07 \mathrm{t} / \mathrm{ha}$ and $8.13 \mathrm{t} / \mathrm{ha}$ in both agricultural and contaminated soils of Narayanganj and Gazipur respectively with high input cost. But the treated pots with $50 \%$ effluent $+50 \%$ fresh water $+50 \%$ RDF gave second highest vegetative weight with low cost in both the agricultural soils, which were $8.25 \mathrm{t} / \mathrm{ha}$ and 7.87 t/ha in Narayanganj and Gazipur agricultural soil, respectively.
\end{abstract}

Key words: Jute leaves, effluent, yield, irrigation.

\section{INTRODUCTION}

Textile industry is one of the most important and rapidly developing industrial sectors in Bangladesh. It is the most important economic sector of the country. Textile industry releases highly polluted and toxic waste waters which are discharged into sewers and drains without any kind of treatment (Islam et al. 2011). Waste water containing nutrients can be used extensively for irrigation. It can be considered as both a resource and a problem. Previous studies revealed that textile mill effluents particularly at higher concentration inhibit the germination and growth of crop plant seedlings (Dutta and Biossya 1997, Singh et al. 2006), adversely affect soil fertility (Nema et al. 1990, Castro et al. 2015) and crop productivity (Ajmal and Khan 1985, Carr et al. 2011). Jute leaves are widely used as a leafy vegetable in many Asian, African and European countries (Furumnto et al. 2002, Velempini 2003, Oyedele 2006). Leafy vegetables play an important role in human diets due to their ability to supply protein, energy, minerals, vitamins and certain hormone precursors (Antia et al. 2006). The jute leaves are used in the treatments of many diseases and have wide antibacterial properties (Ngomuo et al. 2017). Indigenous leafy vegetables are fairly easy to cultivate in terms of pest and disease control while producing very stable yields even under difficult climatic condition (Cunninghum et al. 1992). Bangladesh has immense prospect for exporting vegetables to the world market and it has also produced high quality exportable fresh vegetables (Hoq et al. 2012). Besides, the vegetables meet up the domestic demands of the country. Keeping all these facts in view, an attempt has been made to assess the effect of textile effluents on the yield components of jute vegetables (Corchorus capsularis) (locally known as pat shak).

\section{MATERIAL AND METHODS}

A pot experiment was carried out in the premises of Bangladesh Jute Research Institute, Central Station, Dhaka. Waste water and soil samples were collected from Gazipur and Narayanganj districts. 
Most of our textile mills are situated in those locations. The soil samples were collected from 0-15 $\mathrm{cm}$ plough layer. The soil samples were air dried, ground and screened to pass through a $2.0 \mathrm{~mm}$ sieve and then mixed thoroughly to make it a composite sample. Dry roots, grasses and other vegetative residual parts were removed from the soil. One $\mathrm{kg}$ of each composite sample was taken in a plastic container for chemical analysis. One litter of textile waste water was also taken in a plastic bottle. Then, the physical and chemical characteristics of the soils and water were determined. The recommended methods were followed for the determination of the following properties: DO of water (O meter), BOD of water (DO meter), TDS of water (Hanna instrument), Organic matter content of soils (Walkley and Black 1934 ), Particle size analysis ( Marshall 1951), pH ( Jackson 1973), Electrical conductivity of soil and water from saturation extract, total inorganic elements in water following colorimetric and atomic absorption spectro photometer as required (Jackson 1973, Black 1965, Haq and Alam 2005).

Each earthen pot was filled up with seven $\mathrm{kg}$ of air dried soil. Two sets of experiments for agricultural and contaminated soils were executed with six treatments. The treatments of the experiment were as bellows: $\mathrm{T}_{1}=100 \% \mathrm{FW}\left(\right.$ Control); $\mathrm{T}_{2}=100 \% \mathrm{FW}+100 \% \mathrm{RDF} ; \mathrm{T}_{3}=50 \%$ effluent $+50 \% \mathrm{FW}$ $+25 \% \mathrm{RDF} ; \mathrm{T}_{4}=50 \%$ effluent $+50 \% \mathrm{FW}+50 \% \mathrm{RDF} ; \mathrm{T}_{5}=100 \%$ effluent $+25 \% \mathrm{RDF} ; \mathrm{T}_{6}=100 \%$ effluent $+50 \%$ RDF (where, FW= Fresh Water, RDF= Recommended Dose of Fertilizer). The randomized complete block design was followed with three replications. The vegetable jute variety was used as a test crop. Fifty healthy seeds were sown in each pot. Half dose of urea, full dose of TSP, MoP, fresh and west water were incorporated to soil a day before sowing according to the treatments. Remaining half of the amount of urea was top dressed after 15 days of sowing. All the inter cultural operations were done accordingly. No infection of insecticides and pesticides was observed during jute vegetable growth. The crop was allowed to grow for 45 days. All the needful data were collected. Post harvest soil samples were taken. The numbers of leaves, weight of fresh leaves, green weight of whole plants, weight of root and plant height were recorded from randomly selected 10 plants of each pot.

\section{RESULTS AND DISCUSSION}

Initial physical and chemical properties of the experimental soils are presented in the table 1 . Here we found that the textural class of all the soils are silt loam. $\mathrm{pH}$ of the soils are 6.8, 6,9, 5.9 and 6.6 in ASN, CSN, ASG and CSG, respectively. EC of the soils are 1.6, 1.9, 1.5 and $4.2 \mathrm{ds} / \mathrm{m}$ in ASN, CSN, ASG and CSG, respectively. We observed that organic matter content of the both contaminated soils are comparatively higher than agricultural soils, which are 3.82 and $2.69 \%$ in CSN and CGS, respectively. We also found that $\mathrm{Zn}$ content of the both contaminated soils are also high, which are 5.67 and 19.38 ppm in CSN and CGS, respectively.

Table 1. Initial physical and chemical properties of experimental soils.

\begin{tabular}{lllll}
\hline Parameters & ASN & CSN & ASG & CSG \\
\hline Textural class & Silt Loam & Silt Loam & Silt Loam & Silt Loam \\
pH & 6.8 & 6.9 & 5.9 & 6.6 \\
EC $(\mathrm{dS} / \mathrm{m})$ & 1.6 & 1.9 & 1.5 & 4.2 \\
Organic matter $(\mathrm{OM}) \%$ & 1.77 & 3.82 & 1.78 & 2.69 \\
Total Nitrogen $(\mathrm{N}) \%$ & 0.187 & 0.091 & 0.12 & 0.135 \\
Potassium $(\mathrm{K})$ meq/100g soil & 0.18 & 0.10 & 0.62 & 0.49 \\
Calcium $(\mathrm{Ca})$ meq/100g soil & 4.16 & 3.12 & 3.76 & 5.08 \\
Magnesium $(\mathrm{Mg})$ meq/100g soil & 1.22 & 0.88 & 0.81 & 1.45 \\
Phosphorus (P) ppm & 6.20 & 17.16 & 4.24 & 5.21 \\
Sulphur (S) ppm & 16.73 & 11.22 & 14.03 & 33.25 \\
Copper $(\mathrm{Cu}) \mathrm{ppm}$ & 0.24 & 0.56 & 0.82 & 0.22 \\
Manganese $(\mathrm{Mg})$ ppm & 12.52 & 12.79 & 16.05 & 13.02 \\
Zinc (Zn) ppm & 1.46 & 5.67 & 0.9 & 19.38 \\
\hline
\end{tabular}

ASN=Agricultural soil of Narayanganj, CSN= Contaminated soil of Narayanganj, G=Agricultural soil of Gazipur, CSN= Contaminated soil of Gazipur. 
Table 2 shows that the $\mathrm{pH}$ of the waste water is 7.99 and 7.32 in Narayanganj and Gazipur textile waste water respectively. EC are 2.39 and $2.09 \mathrm{ds} / \mathrm{m}$, respectively in Narayanganj and Gazipur textile waste water. It is seen that total nitrogen content are high in both waste water, which are about 0.05 and $0.07 \%$ in Narayanganj and Gazipur textile waste water respectively.

Table 2. Analytical results of textile waste water of Natayangonj and Gazipur from two different stations.

\begin{tabular}{lcc|lcc}
\hline $\begin{array}{l}\text { Water } \\
\text { parameters }\end{array}$ & Narayanganj & Gazipur & $\begin{array}{l}\text { Water } \\
\text { parameters }\end{array}$ & Narayanganj & Gazipur \\
\hline $\mathrm{pH}$ & 7.99 & 7.32 & $\mathrm{~S}(\mathrm{ppm})$ & 201.60 & 113.72 \\
$\mathrm{EC}(\mathrm{dS} / \mathrm{m})$ & 2.39 & 2.09 & $\mathrm{Cu}(\mathrm{ppm})$ & 1.23 & 1.12 \\
$\mathrm{TDS}(\mathrm{ppm})$ & 1191 & 752 & $\mathrm{Fe}(\mathrm{ppm})$ & 1.06 & 1.34 \\
$\mathrm{DO}(\mathrm{ppm})$ & 0.28 & 0.19 & $\mathrm{Mn}(\mathrm{ppm})$ & 0.206 & 0.097 \\
$\mathrm{BOD}(\mathrm{ppm})$ & 2.85 & 1.39 & $\mathrm{Zn}(\mathrm{ppm})$ & 0.11 & 0.08 \\
Total N $(\%)$ & 0.05 & 0.07 & $\mathrm{~Pb}(\mathrm{ppm})$ & 0.0001 & 0.0001 \\
$\mathrm{~K}(\mathrm{ppm})$ & 1.10 & 0.52 & $\mathrm{Cd}(\mathrm{ppm})$ & 0.0063 & 0.0095 \\
$\mathrm{Ca}(\mathrm{ppm})$ & 1.10 & 0.58 & $\mathrm{Ni}(\mathrm{ppm})$ & 0.274 & 0.482 \\
$\mathrm{Mg}(\mathrm{ppm})$ & 0.33 & 0.20 & $\mathrm{Cr}(\mathrm{ppm})$ & 0.100 & 0.152 \\
$\mathrm{P}(\mathrm{ppm})$ & 58.72 & 64.32 & - & & - \\
\hline
\end{tabular}

Total numbers of the leaves of deshi pat shak -1 per pot are shown in Table 3. The treatment $\mathrm{T}_{2}(100 \% \mathrm{FW}$ $+100 \%$ RDF) showed the highest yield of jute leaves in both the agricultural soils, which were 105 and 113 in Narayanganj and Gazipur agricultural soils, respectively. It is observed that the application of waste water in agricultural soils reduced the number of leaves per pot except in the $\mathrm{T}_{4}$ both in Narayanganj and Gazipur soils, which are respectively $10.99 \%$ and $8.33 \%$ more as compared with control (Table 3). Waste water application also showed negative effect on the contaminated soils in Narayanganj and Gazipur except in the treatments $\mathrm{T}_{3}$ and $\mathrm{T}_{5}$ of the contaminated soil of Narayanganj. These results have similarity with Begum et al. (2011), who reported that the textile industrial waste water exerted a significant negative influence on the yield of rice.

Table 3. Total numbers of the leaves of deshi pat shak $-1 /$ pot.

\begin{tabular}{lcccccccc}
\hline Soils & \multicolumn{9}{c}{ Treatments } & \multicolumn{3}{c}{ LSD } \\
\cline { 2 - 9 } & $\left.\mathbf{( T}_{\mathbf{1}}\right)$ & $\left.\mathbf{( T}_{\mathbf{2}}\right)$ & $\left(\mathbf{T}_{\mathbf{3}}\right)$ & $\left(\mathbf{T}_{\mathbf{4}}\right)$ & $\mathbf{( \mathbf { T } _ { \mathbf { 5 } } )}$ & $\mathbf{( \mathbf { T } _ { \mathbf { 6 } } )}$ & $\mathbf{0 . 0 5 \%}$ & $\mathbf{0 . 0 1 \%}$ \\
\hline Agricultural soil of Narayanganj & 91 & 105 & 87 & 101 & 86 & 89 & 2.25 & 3.53 \\
Contaminated soil of Narayanganj & 82 & 89 & 100 & 79 & 88 & 76 & 3.72 & 5.22 \\
Agricultural soil of Gazipur & 96 & 113 & 95 & 104 & 91 & 100 & 3.77 & 5.29 \\
Contaminated soil of Gazipir & 93 & 105 & 82 & 89 & 87 & 83 & 3.84 & 5.39 \\
\hline
\end{tabular}

Significant treatment difference was observed in the fresh weight of leaves (Table 4). The highest weight of jute leaves with fresh water irrigation in the treatment $\mathrm{T}_{2}(100 \% \mathrm{FW}+100 \% \mathrm{RDF})$ yielded 11.62 and $11.71 \mathrm{t} / \mathrm{ha}$ in agricultural and contaminated soils, respectively of Narayanganj, and 13.15 and $12.29 \mathrm{t} / \mathrm{ha}$ in the same type of soils, respectively of Gazipir. In agricultural soils the value of the leaves weight increased with the effluent application over the control.

Table 4. Total weight of the fresh leaves (t/ha) of deshi pat shak $\mathbf{- 1}$.

\begin{tabular}{lcccccccc}
\hline Soils & \multicolumn{3}{c}{ Treatments } & \multicolumn{3}{c}{ LSD } \\
\cline { 2 - 9 } & $\left.\mathbf{( T}_{\mathbf{1}}\right)$ & $\left.\mathbf{( T}_{\mathbf{2}}\right)$ & $\left.\mathbf{( T}_{\mathbf{3}}\right)$ & $\mathbf{( \mathbf { T } _ { \mathbf { 4 } } )}$ & $\mathbf{( \mathbf { T } _ { \mathbf { 5 } } )}$ & $\mathbf{( \mathbf { T } _ { \mathbf { 6 } } )}$ & $\mathbf{0 . 0 5 \%}$ & $\mathbf{0 . 0 1 \%}$ \\
\hline Agricultural soil of Narayanganj & 3.20 & 11.62 & 4.98 & 9.28 & 5.63 & 9.24 & 0.03 & 0.04 \\
Contaminated soil of Narayanganj & 9.15 & 11.71 & 8.76 & 8.97 & 7.27 & 8.68 & 0.04 & 0.05 \\
Agricultural soil of Gazipur & 3.04 & 13.15 & 6.55 & 11.41 & 5.54 & 10.87 & 0.04 & 0.05 \\
Contaminated soil of Gazipir & 10.33 & 12.29 & 9.08 & 10.18 & 10.30 & 9.32 & 0.05 & 0.07 \\
\hline
\end{tabular}


The Nagayangonj agricultural soil contributed $190 \%$ more leaves yield due to the treatment $\mathrm{T}_{4}(50 \%$ effluent $+50 \% \mathrm{FW}+50 \% \mathrm{RDF})$ and $188.75 \%$ with $\mathrm{T}_{6}(100 \%$ effluent $+50 \% \mathrm{RDF})$ as compared with the control. Similarly in the Gazipur agricultural soil, $275.33 \%$ higher leaves yield occurred in the treatment of $\mathrm{T}_{4}(50 \%$ effluent $+50 \% \mathrm{FW}+50 \% \mathrm{RDF})$ and $257.57 \%$ in the treatment the $\mathrm{T}_{6}(100 \%$ effluent $+50 \%$ RDF) than the control. Results showed that in both Narayangonj and Gazipur contaminated soils, the fresh water application increased the leaf weight, but application of waste water reduced the leaf weights. The contaminated soil with textile west water had negative effect on the weight of jute vegetable leaves.

The results of green plant weight per pot irrigated with different concentration of fresh and waste water are presented in Table 5. The results revealed that the fresh water irrigation along with $100 \% \mathrm{RDF}$ $\left(\mathrm{T}_{2}\right)$ showed the best effect on the yield of green plant weight in all the soils, which were 8.83 and 8.93, t/ha in both the agricultural and contaminated soils, respectively of Narayanganj and 9.07 and $8.13 \mathrm{t} / \mathrm{ha}$ in the same type of soils Gazipur. With effluent application to both the soils, the second highest plant weight was found in the agricultural soil with $\mathrm{T}_{4}$. In the Narayanganj and Gazipur agricultural soils, the treatment $\mathrm{T}_{4}$ displayed that the weights of plant per pot were 8.25 and $7.87 \mathrm{t} / \mathrm{ha}$, respectively which were 139.83 and $133.53 \%$, respectively higher as compared to the control. These results showed similarity with Pandey and Singh (2015); they stated that the high value of yield parameter of waste water irrigated wheat crop indicated the positive impact of waste water irrigation. The results also revealed that in both contaminated soils fresh water application increased the weight of green plant leaves, but application of effluent along with fertilizers reduced it.

Table 5. Green weight of plants of deshi pat shak -1 (t/ha).

\begin{tabular}{lcccccccc}
\hline \multirow{2}{*}{ Soils } & \multicolumn{4}{c}{ Treatments } & \multicolumn{3}{c}{ LSD } \\
\cline { 2 - 9 } & $\left.\mathbf{( T}_{\mathbf{1}}\right)$ & $\left.\mathbf{( T}_{\mathbf{2}}\right)$ & $\left(\mathbf{T}_{\mathbf{3}}\right)$ & $\left.\mathbf{T}_{\mathbf{4}}\right)$ & $\left.\mathbf{( T}_{\mathbf{5}}\right)$ & $\mathbf{T}_{\mathbf{6}} \mathbf{0 . 0 5 \%}$ & $\mathbf{0 . 0 1 \%}$ \\
\hline Agricultural soil of Narayanganj & 3.44 & 8.83 & 4.06 & 8.25 & 3.54 & 5.84 & 0.06 & 0.09 \\
Contaminated soil of Narayanganj & 7.29 & 8.93 & 5.72 & 6.18 & 5.04 & 5.96 & 0.85 & 1.19 \\
Agricultural soil of Gazipur & 3.37 & 9.07 & 4.73 & 7.87 & 3.25 & 6.41 & 0.06 & 0.08 \\
Contaminated soil of Gazipir & 7.06 & 8.13 & 6.27 & 7.23 & 7.46 & 5.90 & 0.10 & 0.14 \\
\hline
\end{tabular}

The results of average plant height $(\mathrm{cm})$ with different concentrations of waste water have been presented in Figures (1to 4). In which the treatment $\mathrm{T}_{2}(\mathrm{FW}+100 \% \mathrm{RDF})$ shows the best positive effect on jute vegetable plant height. These findings have also similarity with Begum et al. (2011), who stated that fresh water irrigation produced the tallest plants because it contained considerable amount of macro and micro- nutrients and contained heavy metals within permissible limit. It was also found that application of different combinations of effluent have showed + ve effect on plant height of jute vegetables as compared to the control in both Narayangonj's and Gazipur's agricultural soils (Figs. 1 and 3). Both Narayangonj and Gazipur agricultural soil showed the tallest plant with the application of $100 \% \mathrm{FW}+100 \% \mathrm{RDF}\left(\mathrm{T}_{2}\right)$, which was about 64 and $69.7 \%$, respectively more as compared to the control. But, in both the soils, we got the next taller plant with the application of $50 \%$ effluent $+50 \%$ $\mathrm{FW}+50 \% \mathrm{RDF}\left(\mathrm{T}_{4}\right)$, resulted about 42 and 50\%, respectively more as compared to the control.

In both the contaminated soils of Narayangonj and Gazipur negative effects were observed on plant height with the application of waste water (Figs. 2 and 4). It was a little increase in plant height with the application of $100 \% \mathrm{FW}+100 \% \mathrm{RDF}\left(\mathrm{T}_{2}\right)$ in both the contaminated soils. In Narayangonj soil, it was $12.5 \%$ and in Gazipur soil it was about $1.4 \%$ more as compared to the control. Except for injury to the roots, a reduction in the root-shoot ratio is almost always in response to more favorable growing conditions (Table 6). An increase in the root-shoot ratio, on the other hand, would indicate that a plant was probably growing under less favorable condition (Richard 1992). The agricultural soils showed the 
lowest root-shoot ratio with the treatment $\mathrm{T}_{2}(100 \% \mathrm{FW}+100 \% \mathrm{RDF})$, which are 0.15 and 0.13 in Narayanganj and Gazipur agricultural soils, respectively. It might be due to adequate nutrient supply in irrigation water enhancing root shoot growth and thereby gave the lowest root-shoot ratio. It was also found that with effluent irrigation the treatment $\mathrm{T}_{4}(50 \%$ effluent $+50 \%$ RDF) root-shoot ratio was lower than other treatments, which indicate that this treatment condition was more favorable for plant than other treatments with effluent application (Table 6).

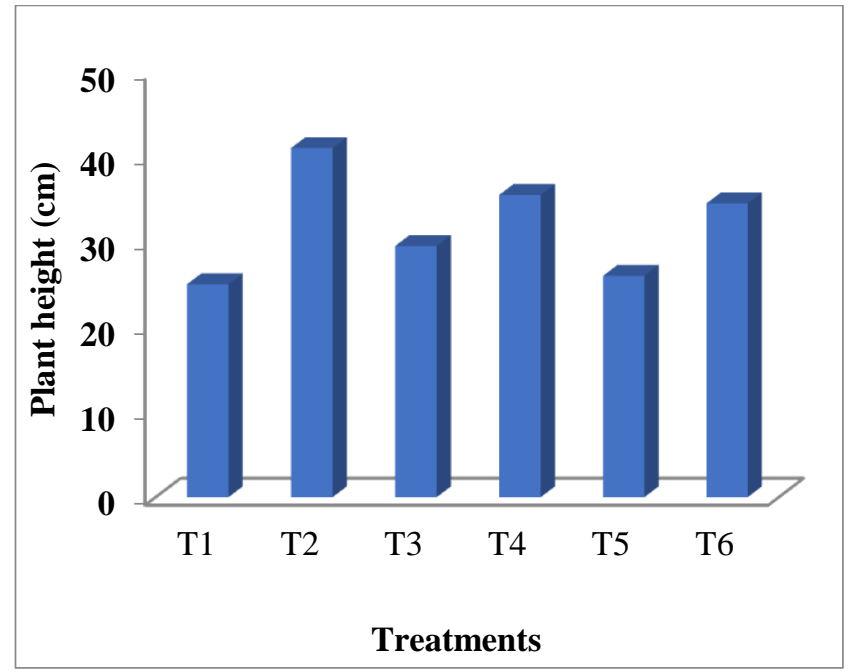

Fig. 1. Effect of effluent on the plant height of Deshi pat shak-1 in the agricultural soil of Narayangonj.

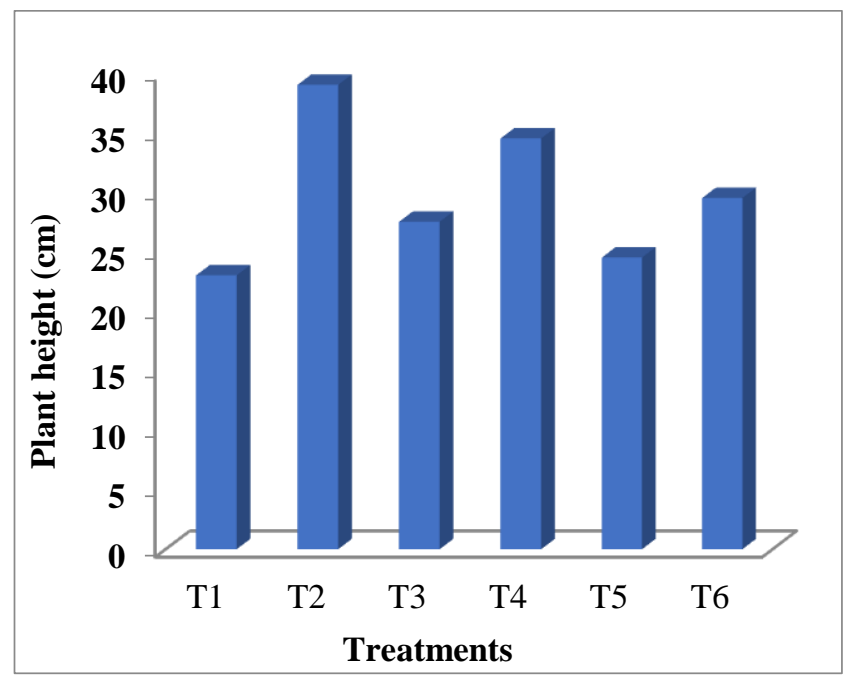

Fig. 3. Effect of effluent on the plant height of Deshi pat shakin the agricultural soil of Gazipur.

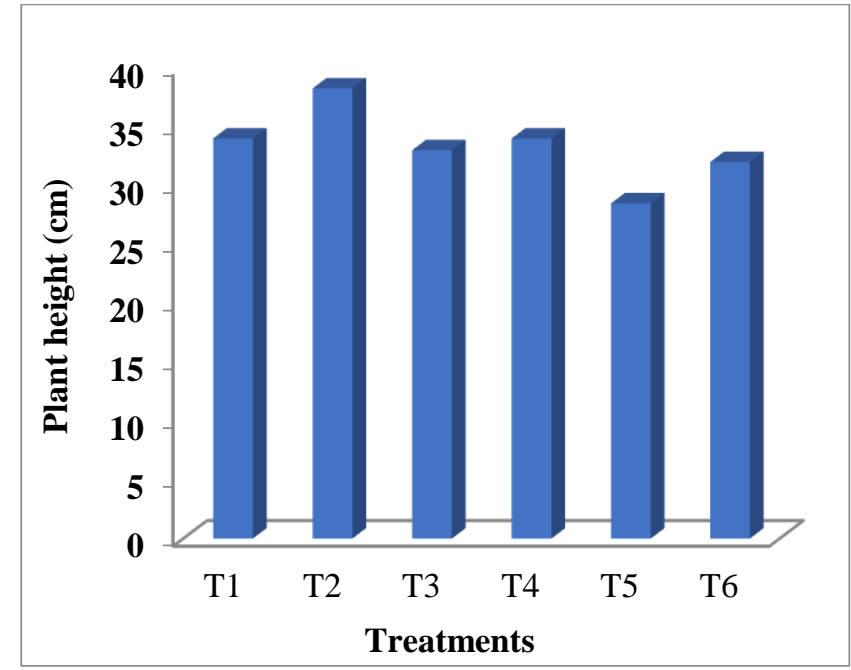

Fig. 2. Effect of effluent on the plant height of Deshi pat shak-1 in the contaminated soil of Narayangonj.

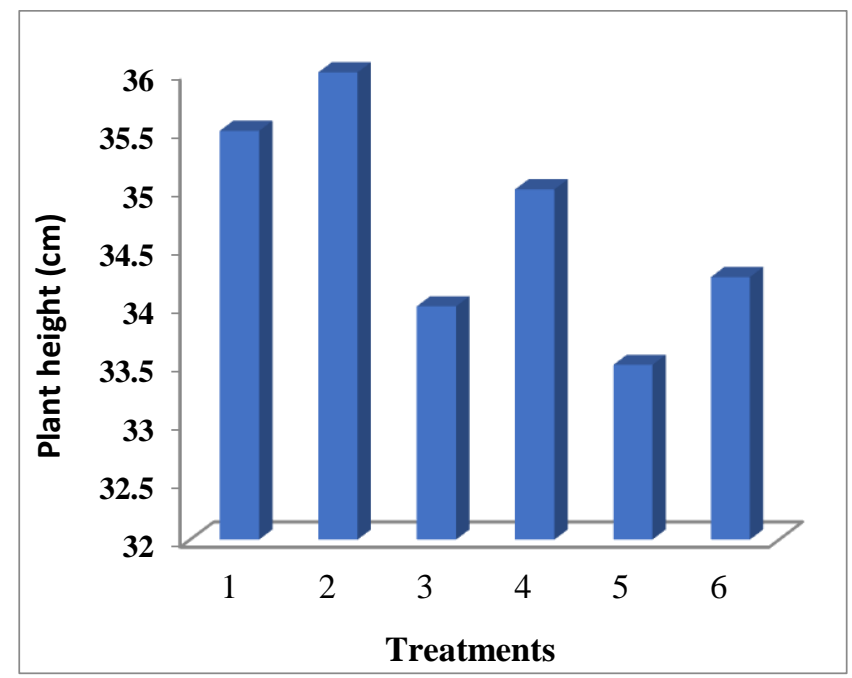

Fig. 4. Effect of effluent on the plant height of Deshi pat shak in the contaminated soil of Gazipur.

Similarly, in the contaminated soil of Narayanganj, the $\mathrm{T}_{4}(50 \%$ effluent $+50 \% \mathrm{FW}+50 \% \mathrm{RDF})$ was also found more favorable than other treatment combinations. But, in the contaminated soil of Gazipur, the $\mathrm{T}_{3}(50 \%$ effluent $+50 \% \mathrm{FW}+25 \% \mathrm{RDF})$ treatment combination was more favorable than other treatments.

The overall results of the different concentration of effluent and fresh water irrigation on jute vegetables growth and yield parameters showed positive impact on agricultural soils over the control. 
The positive impact of textile effluent on jute vegetables was due to having rich nutrients, i.e. N, P, K and $\mathrm{S}$, in it, which nourish the crop better than the control one. But textile effluent irrigation on contaminated soils showed negative effect on the growth and yield parameter of jute vegetables.

Table 6. Root-shoot ratio of deshi pat shak -1/pot in six treatments.

\begin{tabular}{|c|c|c|c|c|c|c|c|c|}
\hline \multirow[t]{2}{*}{ Soils } & \multicolumn{6}{|c|}{ Treatments } & \multicolumn{2}{|c|}{ LSD } \\
\hline & $\left(\mathbf{T}_{1}\right)$ & $\left(\mathbf{T}_{2}\right)$ & $\left(\mathbf{T}_{3}\right)$ & $\left(\mathbf{T}_{4}\right)$ & $\left(\mathbf{T}_{5}\right)$ & $\left(T_{6}\right)$ & $0.05 \%$ & $0.01 \%$ \\
\hline Agricultural soil of Narayanganj & 0.21 & 0.15 & 0.22 & 0.15 & 0.23 & 0.17 & 0.06 & 0.09 \\
\hline Contaminated soil of Narayanganj & 0.16 & 0.16 & 0.19 & 0.15 & 0.17 & 0.17 & 0.03 & 0.04 \\
\hline Agricultural soil of Gazipur & 0.19 & 0.13 & 0.18 & 0.16 & 0.25 & 0.18 & 0.03 & 0.04 \\
\hline Contaminated soil of Gazipir & 0.16 & 0.15 & 0.14 & 0.15 & 0.16 & 0.17 & 0.02 & 0.03 \\
\hline
\end{tabular}

Results showed that textile effluent in contaminated soils is not suitable for the growth of jute vegetables. Statistically the achievements indicate that there was little difference between the $\mathrm{T}_{2}$ and $\mathrm{T}_{4}$ treatments. So, it may be suggested that the treatments $T_{2}$ and $T_{4}$ may be suitable for the cultivation of the new vegetable variety deshi pat shak-1.

\section{ACKNOWLEDGEMENT}

The authors gratefully acknowledge the honourable Prime Minister for awarding the scholarship to do the valuable research work. The VC of the University of Barisal is acknowledged for allowing the researcher to conduct the research under his kind concern. BJRI authority is thanked for providing pots and laboratory facilities.

\section{REFERENCES}

Ajmal, M. and A. U. Khan. 1985. Effect of textile factory effluent on soil and crop plants. Environment Pollution (Series A). 37: 131-148.

Antia, B. S., E. J. Akpan, P. A. Okon and I. U. Umoren. 2006. Nutritive and anti-nutritive evaluation of sweet potatoes (Ipomoea batatas) leaves. Pak. J. Nutr. 5: 166-168.

Begum, R. A., M. W. Zaman, A. T. M. A. I. Mondol, M. S. Islam and K. M. F. Hossain. 2011. Effect of textile industrial waste water and uptake of nutrients on the yield of rice. Bangladesh J. Agril. Resh. 36(2): 319-331.

Black, C. A. 1965. Methods of soil analysis. Part 2. Agron. Ser. Am. Soc. 9: 1149-1178.

Carr, G., R. B. Potter and S. Nortcliff. 2011. Water reuse for irrigation in Jordan: Perceptions of water quality among farmers. Agr. Water Manag. 98(5): 847-854.

Castro, C. B., A. R. Lopes, I. V. Moreira, E. F. Silva, C. M. Manaia and O. C. Nunes. 2015. Wastewater reuse in irrigation: A microbiological perspective on implication in soil fertility and human and environmental health. Environ. Int. 75: 117-135.

Cunningham , A. B., P. J. Jager and L. C. B. Hansen. 1992. The indigenous plant use programme. Fou. Res. Dev. 2: 53-62.

Dutta, S. K. and C. L. Biossya. 1997. Effect of Paper Mill Effluent on Germinations of Rice Seed (Oryza sativa L. VarMahsuri) and Growth Behaviour of its Seedlings. J. Ind. Poll. Con. 13(1): 41-47. 
Furumuto, T., R. Wang, K. Okazaki, F. A. Hasan and I. M. Ali. 2002. Antitumor promoters in leaves of jute (Corchorus capsularis and Corchorus olitorius). Food Sci. Technol. Res. 8: 329-243.

Haq, S. M. I. and M. D. Alam. 2005. A hand book of Analysis of Soil, Plant and Water. BACER-DU, University of Dhaka, Bangladesh.

Hoq M. S., S. K. Raha and N. Sultan. 2012. Value addition in vegetables production, processing and export from Bangladesh. Bangladesh J. Agri. Res. 37: 377-388

Islam M. M, K. Mahmud, O. Faruk and M. S. Billah. 2011. Textile Dyeing Industries in Bangladesh for Sustainable Development. Int. J. Environ. Sci. Dev. 2: 6-16.

Jacson, M. L. 1973. Soil Chemical Analysis. Prentice Hall, Inc. Engle wood cliffs, N. J., USA.

Marshall, C. E. 1951. Proportion of sand, silt and clay in the basic soil textural classes. U. S. Department of agriculture. Hand book No. 18. Soil Survey Manual, USA. 503 pp.

Nema, P., S. S. Rathore and H. S. Nema. 1990. Effect of textile effluent seepage on water quality and soil fertility. Trans. ISDT. 15: 9-16.

Ngomuo, M., T. Stoilova, T. Feyissa, N. Kassim and P. K. Ndakidemi. 2017. The genetic diversity of leaf vegetable jute mallow (Corchorus spp.). Indian J. Agric. Res. 51(5): 405-412.

Oyedele, D. J., C. Asonugho and O. O. Awotoye. 2006. Heavy meatals in soil and accumulation by edible vegetables after phosphate fertilizer application. Elect. J. Agric. Food Chem. 5: 1446-1453.

Pandey, R. and J. Singh. 2015. Effect of textile factory effluent irrigation on productivity of wheat crop. Int. J. Sci. Environ. Tech. 4: 727-736.

Richard, W. H. 1992. Root-shoot ratios. J. Arboriculture. 18(1): 39-42.

Singh, P. P., M. Mall and J. Sing. 2006. Impact of fertilizer factory effluent on seed germination, seedling growth and chlorophyll content of gram (Ciceraeritenum). J. Environ. Biol. 27(1): 153-156.

Velempini, P., I. Riddoch and N. Batisami. 2003. Seed treatments for enhancing germination in wild okra (C. olitorius ). Exp. Agric. 39: 441-447.

Walkley, C. T. and C. A. Black. 1934. An examination of method for determining soil organic matter and proposed modification for chromic acid titration method. Soil Sci. 37: 29-38. 
